\title{
EVOLUTION OF THE LOWEST AMAZON BASIN MODELED FROM THE INTEGRATION OF GEOLOGICAL AND SRTM TOPOGRAPHIC DATA
}

AUTHORS: Dilce F. Rossetti* and Márcio M. Valeriano

${ }^{*}$ Corresponding author:

DILCE DE FÁTIMA ROSSETTI

INSTITUTO NACIONAL DE PESQUISAS ESPACIAIS-INPE

CENTRO DE OBSERVACÃO DA TERRA

DIVISÃO DE SENSORIAMENTO REMOTO-DSR

RUA DOS ASTRONAUTAS 1758- JARDIM DA GRANJA--CP 515

SÃO JOSÉ DOS CAMPOS- CEP 12245-970 SÃO PAULO BRASIL

Fone: (012) 39456451 Fax: (012)39456488

e-mail: rossetti@dsr.inpe.br

SHORT RUNNING TITLE: EVOLUTION OF THE LOWEST AMAZON BASIN 


\title{
EVOLUTION OF THE LOWEST AMAZON BASIN MODELED FROM THE INTEGRATION OF GEOLOGICAL AND SRTM TOPOGRAPHIC DATA
}

\author{
Dilce F. Rossetti ${ }^{\mathrm{a}}$ and Márcio M. Valeriano ${ }^{\mathrm{a}}$ \\ Instituto Nacional de Pesquisas Espaciais-INPE, Rua dos Astronautas 1758-CP 515, 12245-970 São José dos \\ Campos-SP, Brazil \\ *Corresponding author: \\ E-mail address: rossetti@dsr.inpe.br (D.F. Rossetti).
}

\begin{abstract}
Morphologic features obtained from SRTM data, integrated with geologic information, are emphasized in this paper in order to provide the basis for understanding the development of the lowest Amazon drainage basin, focusing on the history of one of the largest Amazonian tributaries, the Tocantins River, and on the origin of the Marajó Island, throughout the Quaternary. This approach led to the recognition of a fan morphology related to the record of a tectonically controlled N/NW-S/SE orientated paleovalley cut down into Miocene and older rocks. The incised valley was fed by a paleo Tocantins River, which deposited its sediment load continuously to the north-northwest, reaching the Marajó Island and producing a deposit displaying a fan-morphology during the PlioPleistocene/Pleistocene. As characterized in the SRTM images, this channel system became abandoned due to capture by NE-SW orientated faults and establishment of the Pará River by W-E strike slip movements. This event, which probably took place in the Mid-Holocene, was responsible for detachment of the Marajó Island from the mainland.
\end{abstract}


Keywords: SRTM imagery, topographic model, landscape evolution, Quaternary, Amazonian, geology.

\section{Introduction}

The Amazon fluvial system is extraordinary, having the largest volume discharge (i.e., $175,000 \mathrm{~m}^{3} / \mathrm{s}$ ) in the world, with flows that reach more than $6,400 \mathrm{~km}$ of length. Although representing a unique system, there are only a few works dealing with the Amazon drainage basin and, in particular, no efforts have been presented attempting to provide the history of the main river or of their tributaries through time. This type of study is important to help understanding the mode of formation and evolution of this large river system, which can be used as an analog for reconstructing similar fluvial systems in the ancient record.

The lack of detailed studies, the great size and, many times, the inaccessible nature of Amazonia, are aspects favorable for the application of remote sensing as an important tool for the characterization of their physical environments (Moran \& Brondizio, 1994). Given that processes involving sediment transport, erosion and weathering are directly imprinted in the land surface, the study of morphological properties might be important to help accessing the geological history in this particular area. In particular, interpretations derived from remote sensing data might be of great help for identifying features of the physical environment developed throughout the Quaternary, which have a great potential to be still preserved on the modern landscape. 
In this paper, a general morphologic characterization of the lowest Amazon drainage basin is provided with basis on the interpretation of data provided by the Shuttle Radar Topographic Mission (SRTM). Application of this resource had the advantage of furnishing digital elevation information with minimum influence of vegetation and perennial clouds, both representing major problems for the use of other remote sensing imagery (i.e., Landsat) in the Brazilian Amazonia (Asner, 2001). The goal was to combine spatial analysis with geological data available in the literature in order to: 1 . create the basis for discussing the geologic history of this area during the Late Tertiary-Quaternary, attempting to reconstruct the evolution of one of the main Amazon tributary in its lower course, the Tocantins River; and 2. understand the origin of the largest fluvial island in the world, the Marajó Island. It is also discussed herein how tectonic reactivations have contributed to the geological evolution of this area.

\section{Methods}

This work was based on the integration of sedimentological and structural information available in the literature and new morphologic and topographic data derived from SRTM-90 data. These were downloaded in August 2003 from USGS Seamless Data Distribution System (http://srtm.usgs.gov/data/obtainingdata.html), in the first version, now known by "unfinished" dataset, in TIFF format. Though seamless in its origin, SRTM data were downloaded in tiles correspondent to 1:250,000 quads (Fig. 1) to facilitate storage and avoid overflow. More information about SRTM data itself is presented by Rabus et al. (2003), as well as an increasing number of papers dealing with it. 
SRTM-90m data were resampled (from 3" to 1") in order to achieve improvements for morphometric derivations, as well as interpretation in detailed scales. This procedure followed a geostatistical approach (Valeriano, 2002), through kriging, using the following computational programs: ENVI (Research Systems Incorporation, 2002) for failure correction, sampling and ASCII data export; MINITAB $^{\circledR}$ (MINITAB Incorporation, 2000) for trend analysis and calculation of residues, VarioWin (Pannatier, 1996) for geostatistical analysis, and Surfer (Golden Software, 1995) for kriging interpolation. These procedures, depicted in Valeriano et al. (2006), were shown to improve the results of derivative techniques. Consequently, shaded relief presentations (which are essentially function of the derivatives slope angle and aspect) are also improved, with significant gains for visual interpretation (Fig. 2).

After resampling, the refined DEM was derived into morphometric maps with the application of a suite of algorithms, developed in Idrisi Macro Language (Eastman, 1995). These included aspect (directly from the GIS resources), slope (Valeriano, 2002b), profile curvature (Valeriano, 2003) and plan curvature (Valeriano \& Carvalho Júnior, 2003). A derivation specially developed for visual evaluations of DEM (Valeriano (2002), here called ADD (Azymuth, Drainage and Divides), presents thalwegs and divides overlaid on aspect angle image, codified as brighter colors for northward directions grading to darker tones for southward slopes, thus rendering a type of hill shading. Slope angle images were calculated through the vector sum of slope orthogonal components, as quantified through moving windows in " $\mathrm{x}$ " and "+" orientation systems, taking the maximum vertical displacement in each windowed direction and the maximum resultants between the orientations. This was shown to produce results with higher correlation with controlled 
estimates (Valeriano, 2002b). The method to map profile curvature is based on local $3 \times 3$ pixel windows designed to perform geometrically the second order derivative through the slope profile. Curvature calculations required the DEM spatial resolution as one of the inputs, so as to calculate a slope change rate per horizontal distance as unit, in degrees per meter $(\% \mathrm{~m})$. Since this is calculated towards the eight neighbor pixels of each windowed position, one of the eight results is chosen according to the local slope direction classified in octants. Plan curvature was mapped through a similar application of moving windows, on the slope direction image instead, providing the slope direction change rate per horizontal distance $(\% / m)$ as unit.

Though originally developed for quantitative approach, the morphometric maps were promptly observed together with elevation presentations under visual interpretation. Because of the local character of the derived variables and the regional expression of most of the targeted features, quantitative approach, not developed in this paper, showed to be convenient only after establishing terrain patches, with further statistics. Segmentation or binning techniques, successfully applied by Kellndorfer et al. (2003) to study canopy effects, may represent digital alternatives for visual classification of terrain units in this task. The crispy appearance of derived maps in detailed excerpts (Fig. 3), indicates their high variability in short distances. Besides terrain features, canopy effect was observed to cause a substantial portion of this variability (Valeriano et al., 2006), particularly noticeable on flat terrain.

Image interpretation of elevation data was made possible by the use of the software Global Mapper (Global Mapper Software LLC). Given the very low topography, the study area had to be visualized accordingly using customized shade schemes and palettes to 
efficiently highlight the morphologic features of interest to this paper. Color schemes were rearranged to present strong hue transitions near the height of terrain units boundaries, requiring often adjustments from a local to another.

\section{Geologic framework}

\subsection{Regional geology}

The main central part of the study area is located within the Marajó Graben System. This consists of an elongated area up to $1.5 \times 10^{6} \mathrm{~km}^{2}$ in the northeast of the State of Pará, which has subsided as a result of the extension related to the opening of the Equatorial South Atlantic Ocean during the late Jurassic/early Cretaceous (Azevedo, 1991; Galvão, 1991; Villegas, 1994). The Marajó Graben System configures a northwest to northeast oriented belt formed by four depocenters (Fig. 4), named Cametá and Mocajuba (southeast), Limoeiro (central) and Mexiana (northeast) sub-basins, the latter being located entirely on the continental shelf. Seismic data indicate a sediment pile up to $10 \mathrm{~km}$ thick, with the upper $5.5 \mathrm{~km}$ being represented by Cretaceous syn-rift deposits, including the Breves (Albian to Cenomanian) and Limoeiro (mostly Upper Cretaceous) formations (Fig. 5), and a much thinner (i.e., $900 \mathrm{~m}$ thick) Tertiary post-rift interval (Galvão 1991), referred as the Marajó (Paleocene-Middle Miocene), Tucunaré and Pirarucu (Late Miocene to Pleistocene) formations.

A remaining part of the study area is in the southeastern edge of the Amazonas Basin, and in the Bragantina and Pará platforms. The Amazonas Basin represents a main E- 
W and SW-NE oriented rift formed in the Transamazonic Craton during Early Paleozoic intraplate extension. Its filling consists mostly of Paleozoic rocks, and Cretaceous deposits of the Alter do Chão Formation. The platforms correspond to shallow areas of relative tectonic stability between the Marajó Graben System and other sedimentary basins formed during the South America and African split up.

The lowest Amazon drainage basin is developed in a region strongly affected mostly by NE/SW and E-W strike-slip faults (Szatmari et al., 1987), which started during the establishment of the main rifting during the early Cretaceous, remaining active, though at a lower rates, up to the present (Azevedo 1991; Galvão 1991; Villegas 1994; Bezerra, 2003), regardless of its location in a passive margin. As a result, the study area is dominated by numerous NE/SW, NW/SE-NNW/SSE, and E/W-ENE/WSW faults with offsets of up to several hundreds of meters (Villegas, 1994) that affected not only the Cretaceous, but also the Tertiary and even the Quaternary sedimentation (Costa et al., 1993, 1995; Bemerguy, 1997; Costa \& Hasui 1997; Góes \& Rossetti, 2001) and, ultimately, has a great influence in the development of the modern morphology.

\subsection{Description of the sedimentary units}

The sedimentary units from the lowest Amazon area are of Cretaceous and younger ages. These units, with distinct designations in sub-surface and surface (Fig. 5), are represented in the exposures by the Itapecuru Group (Cretaceous), Pirabas/Barreiras (Late Oligocene/Middle Miocene) and Post-Barreiras sediments (Plio/Pleistocene/Pleistocene). Cretaceous deposits are mostly represented by the Ipixuna Formation, which consists of 
kaolinitized, cross-stratified and parallel-laminated sandstones, interbedded with heterolithic deposits, as well as mudstone and intraformational conglomerates. This unit has been also traditionally interpreted as entirely continental in nature (Góes, 1981), but more recent studies have demonstrated that it includes deposits formed mostly by wave and tidal processes in marginal marine and possibly estuarine settings (Rossetti \& Santos Jr., 2003; Santos Jr. \& Rossetti, 2003; Rossetti, 2004). Exposures of Cretaceous deposits to the west of the Tocantins River are referred to as the Alter do Chão Formation in the Amazonas Basin. The latter deposits are siliciclastic red beds consisting of sandstones and mudstones attributed to continental (e.g., Daemon, 1975) and, more recently, wave-dominated deltaic environments (Rossetti \& Netto, 2005).

The Alter do Chão and Ipixuna formations are unconformably overlain by the Pirabas/Barreiras succession, which include carbonates, mudstones and sandstones that are locally highly fossiliferous, allowing determination of a precise Late Oligocene/Early Miocene age based on micropaleontological data (Arai et al., 1988; Leite et al., 1997). Previous studies emphasizing facies characteristics have led to the recognition of a prograding shelf to shallow marine, lagoon complex (lagoon, tidal delta/washover), tidal channel, and mangrove/tidal flat depositional settings, which are related to estuarine paleovalley systems (Góes et al., 1990; Rossetti, 2001; Rossetti \& Santos Jr., 2004).

The Tertiary deposits, mostly exposed in platform areas, include the Pirabas/Barreiras formations and the Post-Barreiras Sediments. The Pirabas Formation (Late Oligocene-Early Miocene) includes limestones interbedded with black, gray and greenish laminated mudstones and, subordinately, calciferous sandstones (Petri, 1957; Ferreira, 1966; Góes et al., 1990). Fossils are abundant throughout this unit, allowing its 
attribution to the Late Oligocene/Early Miocene (Arai et al., 1988; Toledo, 1989; Arai, 1997; Leite et al., 1997). Inner shelf, lagoon, and mangrove deposits have been recognized in this unit (Ferreira, 1977; Góes et al., 1990). The Barreiras Formation (latest Early Miocene/Middle Miocene) consists of variegated, non-fossiliferous, siliciclastic deposits (conglomerate, sandstone and claystone) overlying the Pirabas Formation (Andrade, 1955; Matoso \& Robertson, 1959). This unit has been traditionally considered as continental in origin (e.g., Góes, 1981); however, studies emphasizing facies analysis revealed a variety of sedimentary features attributed to tidal processes acting within NW/SE trending estuarine systems (Rossetti et al., 1989, 1990; Rossetti, 2004; Rossetti \& Santos Jr., 2004).

The Barreiras Formation is unconformably overlain by the Post-Barreiras sediments, a geographically extensive, but still poorly studied, massive to incipiently stratified unit consisting of light red, moderately to poorly sorted, fine- to coarse-grained sands and massive mudstones, locally highly bioturbated (Rossetti, 2001). The sands are mostly monocrystalline, sub-angular to sub-rounded quartz grains. A PlioPleistocene/Pleistocene age has been estimated for these deposits through stratigraphic relationships, as they overlie the Upper Miocene Barreiras Formation, the later in turn overlain by an unconformity formed by a latest Miocene drop in relative sea level (Rossetti, 2004). Additionally, the Post-Barreiras sediments are overlain by a variety of deposits displaying Holocene ages (Simões, 1981; Costa et al., 1997; Behling \& Costa, 2000; Behling et al., 2001).

\section{Morphologic characterization}


Extensive previous fieldwork, as summarized above, combined with the analysis of available geological maps, reveal that the study area is dominated by deposits of Pleistocene, and possibly also Plio-Pleistocene ages, which are part of the unit referred generically as the Post-Barreiras Sediments. These are characterized by a NNW/SSE elongated belt that starts southward at the locality of Tucuruí, and spreads out continuously northward from the mainland, reaching the southwestern and central parts of the Marajó Island (Fig. 4). Because in plan view, these deposits display a triangular shape that defines a morphology resembling a fan, this term will used throughout the text for descriptive purpose only. The use of this term herein does not imply in the presence of alluvial fans in the study area, as the deposits in this instance were formed mostly in fluvial systems within incised paleovalleys, as discussed below. The fan-like deposits are fringed by Holocene deposits, which are particularly widespread in the eastern and northwestern part of this island.

Analyses of radar data revealed the main morphological aspects of the PostBarreiras Sediments, and of the associated deposits, to be described herein according to their occurrence in the southern, mid and northern sectors of the fan. If in one hand the processed SRTM data did not add much to define the overall fan-like deposits, they were crucial to characterize each individual fan sector described below, allowing a much better description of their morphological aspects, recorded by paleochannels of various sizes.

\subsection{Southern fan sector}


The southernmost and narrower tip of the fan-like deposits is elongated, defining a funnel shape up to $140 \mathrm{~km}$ long, and which range in width from 2-3 km wide upstream in the locality of Tucuruí to $25 \mathrm{~km}$ and $52 \mathrm{~km}$ in the middle and upper reaches, respectively (Fig. 4). Fieldwork revealed that this sector (Fig. 6A) is dominated by the Post-Barreiras Sediments, represented by flat sandy terrains with elevation averaging $30 \mathrm{~m}$ and a main northward-orientated, low density drainage. A few NNW/SSE orientated paleochannels up to $2 \mathrm{~km}$ wide were recognized in the Post-Barreiras Sediments located in the extreme western portion of this sector, paralleling the basement (Fig. 6B). Holocene deposits are present only northward in this sector, where a rapid enlargement is observed. In that area, the Holocene deposits are distinguished by sediments located at altitudes of $12 \mathrm{~m}$ and lower, which are morphologically characterized by abundant abandoned meandering channels and flooded areas. These deposits are intersected by the Tocantins River, which reaches the eastern edge of the sector from this point, running through it.

The Post-Barreiras and Holocene deposits in this southern fan sector are sharply entrenched into rocks that vary northward from Paleozoic to Cretaceous, and then Miocene ages. The Quaternary deposits display edges configuring slope profiles that are smooth in the western side and abrupt in the eastern side. In the latter, the margin stands almost vertically, reaching an altitude of $80 \mathrm{~m}$ (Fig. 6C). Several straight segments displaying NNW-SSE orientation characterize the funnel margins along this sector (Fig. 6A). A north/south elongated relic of Miocene deposits (see white arrows in figure 6A) circa $3 \mathrm{~km}$ wide and $30 \mathrm{~km}$ long occurs in the right margin of the Tocantins River, extending to the southern part of the mid fan sector. 


\subsection{Mid fan sector}

This sector, which represents the point where the fan-like deposits become the largest, includes a central area located between the Tocantins and the Jacundá rivers, and two lateral wings (Fig. 4). The central sector extends for $90 \mathrm{~km}$ in the north/south direction, and $170 \mathrm{~km}$ in the east/west direction. The wing located to the west of the Jacundá River extends throughout almost $90 \mathrm{~km}$ northwestward, reaching the Caxiunã Bay. It has an overall rhombic shape formed by three land masses defined mostly by the courses of the Anapu, Pacajá and the Jacundá rivers. These rivers display segments deflected in a similar pattern from NNW to WNW and then NNW, discharging in the WNW and W-E orientated Pará River at the northern end of the mid fan sector. The modern channels in this area run mostly to NW or NE. The wing to the east of the Tocantins River forms a NE/SW elongated belt that is $165 \mathrm{~km}$ long and up to $50 \mathrm{~km}$ wide, and displays few channels running mostly to NNE.

The Post-Barreiras sediments are the prevailing deposits in all sectors, occurring at altitudes of up to $35 \mathrm{~m}$, with an average of $25 \mathrm{~m}$. In both wings, the Post-Barreiras Sediments do not show paleochannels. However, paleochannels mapped in the southern fan sector continue throughout this area (Fig. 7A), where they show the same orientation and magnitude, though they are more abundant and become branched into several lateral channels. Noteworthy is the eastward inflexion of a main channel at the transition of the southern and the mid fan sectors (white arrow in figure 7A), a pattern that is followed by the Tocantins River, which turns to east through a distance of almost $20 \mathrm{~km}$ at this same position. 
Except for modern alluvial sediments, geological maps do not show any significant Holocene deposits in the mid fan sector. Analyses of radar images, however, revealed volumetrically significant Holocene deposits in the northeastern side of the central area, with two large, and in part seasonally flooded, areas up to $25 \mathrm{~km}$ long and around $15 \mathrm{~km}$ wide (Fig. 7B). Other occurrences of Holocene sediments are recorded in the southern part of the eastern wing, and in the eastern block of the western wing. In all these places, the Holocene deposits occur at altitudes of only 4 to $8 \mathrm{~m}$ (Fig. 7C).

\subsection{Northern fan sector}

The northern fan sector is the largest, encompassing the Marajó Island, as well as several other islands located in the northwest of the study area. Great part of this sector is characterized by Post-Barreiras sediments. This unit extends throughout the Marajó Island, forming a continuous sedimentary succession that extends from the mid fan to this sector. However, the Post-Barreiras sediments disappear northward, where they are replaced by Holocene deposits (Fig. 8A). These are also present in the eastern side of the Marajó Island, where large, periodically flooded areas are abundant. A narrow, but elongated belt up to $100 \mathrm{~km}$ long and averaging $10 \mathrm{~km}$ wide in the eastern part of this island contains elevated areas consisting of deposits representing the Barreiras Formation and the Post-Barreiras sediments (Fig. 8A).

Topographic profiles obtained from SRTM images revealed that areas in the Marajó Island with Holocene sedimentation is located only 2-5 $\mathrm{m}$ above present sea level, while areas with Barreiras and Post-Barreiras sediments might be up to $40 \mathrm{~m}$ (Fig. 8B). The 
altitude in the latter deposits is enhanced due to influence of canopy, as they are covered by ombrophyla forests, as opposed to Holocene sediments with prevailing cerrados. Regardless of the vegetation influence, topographic data reveals a dominance of altitudes averaging $15 \mathrm{~m}$ where the Barreiras and Post-Barreiras deposits are present, with a maximum of $20 \mathrm{~m}$ at the locality of Cachoeira do Arari.

A typical feature of the northern fan sector is the abundance of paleochannels, which are particularly well developed in the western side of the Marajó Island (Figs. 9AD). Some large channels from the southwestern margin of the Marajó Island are in continuity with the NNW-SSE orientated channels described in the southern and mid fan sectors. Features of interest concerning these paleochannels include: a) the subtle disappearance (see arrows in figure 8A), and sometimes the opening forming a funnel shape (Fig. 9C) as they cross into the eastern side of the island where Holocene sedimentation dominates; and b) the frequent dislocation where they are cut by straight structural lineaments (Fig. 9D).

\section{Geological history}

Given the complex nature, the scarcity of detailed studies and the great size, many further cooperative efforts remain to be undertaken before the latest geological events that promoted the development of the modern Amazon drainage basin can be depicted in a robust model. The overall morphological characterization of the lowest Amazon drainage basin presented herein, when linked to the available geological data, can serve for launching this process, allowing a first discussion on the main mechanisms that influenced 
the evolution of the lower reaches of the fluvial system with the largest discharge in the world, as well as of its associated complex of islands.

A key point in this discussion is the primary recognition that the PlioPleistocene/Pleistocene deposits, corresponding to the Post-Barreiras sediments, rather than having a random distribution, configure an elongated, fan-shaped body confined by Miocene and older rocks. Taking into account the relatively young geologic age of these deposits, it is reasonable to consider that such morphology is most likely a reflection of the original geometry of the depositional system.

It is proposed herein that the studied fan-like deposits formed within a large NNW orientated incised paleovalley (Fig. 4). The several NNW-SSE orientated straight segments of the valley margins in the southern fan sector are taken as evidence that the PlioPleistocene/Pleistocene paleovalley was established as a result of faulting, an interpretation that is consistent with the presence of several structural lineaments displaying this orientation in the study area. As previously summarized, the underlying Miocene deposits were also formed within a paleovalley displaying similar orientation. An earlier work has stated that such disposition for the Miocene paleovalley, which also runs parallel to main fault zones, has a tectonic control (Rossetti \& Santos Jr., 2004).

The evolution of the Plio-Pleistocene/Pleistocene paleovalley and of the Tocantins River, which runs paralleling its eastern margin, appears to be closely related. The rapid changes in the course of this river, as reported earlier, coincide with the location of main EW, NNW-SSE and NE-SW strike-slip fault zones that were recurrent through time since at least the Late Tertiary, but which details of evolution remains to be better discussed (Costa et al., 1996, 2001). The NNW segment of the Tocantins River ends exactly at the head of 
the fan, promptly leading to argue that the paleovalley was established along the same fault zone responsible for the deviation of this river from its E-W course. Furthermore, the fan geometry of the Post-Barreiras sediments, with spreading to NNW, implies in the presence of a southeastern clastic supply. This morpholological characteristics, taken together, readily lead to invoke a time when an ancient Tocantins River would have discharged into the Equatorial South Atlantic Ocean through a NNW course (Fig. 10A), as opposed to its modern NE drainage, feeding the paleovalley with sediments brought from the southeast, and accumulating the succession recorded by the Post-Barreiras sediments.

The NNW fault zone that promoted the development of the paleovalley discussed herein must have being active during the Pliocene. This is revealed by the fact that the paleovalley truncates deposits of Miocene and older ages, and it is filled mostly by PlioPleistocene/Pleistocene sediments. Thus, after deposition of the underlying Mid-Miocene Barreiras Formation within an estuarine incised paleovalley formed along a main NW/SE fault zone, there was a prolonged quiescence in the Late Miocene, as recorded by an unconformity with well developed lateritic paleosol that is correlatable throughout the northern Brazilian basins (Rossetti, 2001, 2004; Costa et al., 1996). After this time, instability took place, with tectonic reactivation and consequent sediment accumulation along the new accommodation space promoted by fault displacement.

Evidence for a paleo Tocantins River discharging north-northeastward into the Atlantic are the large, NNW oriented paleochannels preserved in the Post-Barreiras Sediments, as recognized in all fan sectors. The continuity of both the paleochannels and the fan morphology, displayed by the Post-Barreiras succession, into the Marajó Island 
demonstrates that this island was still connected to mainland in the Plio-Pleistocene. The Pará River, then, could not have existed yet.

The fact that the root of the main paleochannels is located right where the modern Tocantins River is inflected to the NE is evidence that they were part of a same river system. NE-SW oriented faults (Costa et al., 1996) were responsible for the capture of the Tocantins River to its modern course, with the consequent abandonment of the NNW oriented channels (Fig. 10B). This process must have taken place in times not older than the Pleistocene, since it cuts through the Post-Barreiras sediments. Previous authors have proposed that this tectonic event took place during the Würm glaciation in the Late Pleistocene (Costa et al., 2002). This fault system might have also lead to the origin of the Caxiuanã bay, located in the western margin of the paleovalley. Radiocarbon dating of this place revealed maximum ages of around $8000{ }^{14} \mathrm{C}$ yr B.P. (Costa et al., 1997; Behling \& Costa, 2000), which conforms to a proposed Late Pleistocene age for the NE-SW tectonic event. The north-south elongated remains of Miocene deposits in the southern and parts of the mid fan sectors are probably a record of the previous eastern margin of the paleovalley. As the NE-SW faults developed and the Tocatins River migrated easternward, it cut down into new Miocene basement, with the consequent enlargement of the paleovalley.

The detachment of the Marajó Island from the mainland is proposed to be as young as the Holocene (Fig. 10C). As mentioned above, the origin of this island is related to the existence of the Pará River. The course of this river consists of several WNW-ESE and ENE-WSW oriented segments located along a main E-W strike-slip fault zone attributed to the Holocene (Costa et al., 1996, 1997, 2001). Good evidence that the main E-W fault system is younger than the NE-SW one are: 1. the deflection of the NE oriented course of 
the Tocantins River to ENE throughout one of these segments; and 2. the deviation of several NE-SW oriented rivers to ESE in the western wing of the fan. The rhombic shape of this fan sector, which is typical of areas undergone to strike-slip motions, attests to the existence of these two faults zones.

The several straight segments that define the northern edge of the Marajó Island parallel another main E-W fault system, which has also been attributed to a strike-slip nature (Costa et al., 1996). The interception of the several paleochannels of the PosBarreiras sediments by these faults attests to its young, post-Pleistocene age. This fault system might have, thus, developed in association with the fault that gave rise to the Pará River in the eastern edge of the Marajó Island. The several narrow ENE-WSW oriented paleochannels mapped inside this island might have been triggered by stress during the development of these fault systems. The fact that these channels intercept the larger, main NNW running fluvial drainage is a proof of their younger age, thus being consistent with its attribution to the E-W Holocene faulting.

Furthermore, it is claimed herein that, before or even simultaneously to detachment, it is possible that the eastern side of the Marajó Island has undergone a slight subsidence (Fig. 10C). This suggestion, though contrary to tectonic models that have proposed an uplift of the eastern Marajó Island since the Pleistocene (Vital, 1988; Costa \& Hasui, 1997), is based on the following evidence: 1 . this part of the island is mantled by sediments of a younger, mostly Late Holocene age, than the western side. The oldest deposits around the Arari Lake show ages of around 6,000 yr B.P. (Vital, 1988); 2. although the whole area is flat (usually below $15 \mathrm{~m}$ of altitute), there is a slight depression in its eastern side where cerrado vegetation dominates and flooded areas become abundant; 3 . the sharp 
disappearance of paleochannels when crossing into this area, suggesting that they once ran through it, but fault dislocation and further Holocene sedimentation contributed to burry them; and 4. the opening of some channels when crossing into this area, forming a funnel shape suggesting an estuarine morphology left behind due to a change in paleocoast position. Bouguer maps show negative anomalies in this part of the Marajó Island, indicating the presence of a major sedimentary depocenter having a NNW-ESE and then NE-SW orientation, which is linked to the Mexiana sub-basin of the Marajó rift system (Azevedo, 1991). Taking this overall depocenter orientation, it is concluded that both the NNW-ESE and the NE-SW fault systems recorded in the study area and the Holocene subsidence of the eastern side of the Marajó Island attest to tectonic reactivations of the Mexiana rift. The bouguer map also indicates important positive anomalies in the extreme eastern edge of this island, revealing that it was not affected by subsidence and explaining why its morphological characteristics resembles those from the middle and western parts of the island, where the Post-Barreiras sediments dominate and flooded areas are in general scarce or absent.

It seems that the subsidence in the eastern Marajó Island was also accompanied by a subsidence of several terrains located in the eastern, and mostly northeastern of the mid-fan sector, which is also characterized by relatively lower altitudes and flooded area.

\section{Final remarks}

The details related to the evolution of the lowest Amazon area remains to be reconstructed, but a preliminary model can already be proposed, which shows that tectonic 
activity was the main factor controlling the distribution of the sedimentary units and the development of the modern morphology. The model presented herein considers the existence of a paleo Tocantins River discharging its flow to the NNW into the Altlantic Ocean, as opposed to its modern NE discharge. This would have resulted in deposition of a sedimentary succession displaying a fan morphology attributed to the infill of a paleovalley developed during the Plio-Pleistocene/Pleistocene due to NNW-S fault reactivation. During that time, the Marajó Island, and probably also most of the many islands that characterizes the lowest Amazon drainage area, was still connected to the mainland. This morphological feature was only formed after the capture of the Tocantins River by NE-SW orientated faults, and the later establishment of the Pará River by W-E strike slip movements. Therefore, a very young, most likely Mid-Holocene age seems more likely.

The present geomorphological characterization based on SRTM data was crucial for recognizing the incised paleovalley in the study area. Application of this method might contribute to substantially increase the geological knowledge in similar areas with difficult access and characterized by an overall lack of information. The great advantage of this procedure is to provide overall models that can serve as the basis to optimize fieldworks aiming to reconstruct the evolution of depositional systems that still keep relics of their past physical environment imprinted on the modern landscape. When combined with regional geological information, the interpretation of geomorphological features using SRTM data revealed to be of great contribution for reconstructing the geological history of the lowest Amazon drainage basin. Based on this work, it could be demonstrated, for the first time, that one of the largest Amazon tributaries, the Tocantins River, had a complex evolution, changing its position according to tectonic reactivations that took place even during the 
Holocene. In addition, the data presented herein served to approach the origin of the Marajó Island, the largest fluvial island in the world, allowing discussing the mechanism that would have promoted its detachment from the mainland. These issues, not emphasized in detail in previous publications, are of wide relevance for studies focusing the Quaternary tectono-sedimentary history of the North Equatorial Brazilian Margin. This work serves also to suggest that the Amazon drainage basin, as presented in the modern landscape, might be a relatively recent scenario. Many possible changes in the river positions due to tectonics might have taken place in past times. These results are of great contribution in studies focusing the distribution of the Amazon biodiversity (e.g., see Rossetti and Toledo, 2006, for a discussion related to this issue).

\section{Acknowledgement}

This work was funded by FAPESP (Project \# 004/15518-6). The authors are scholarship holder of CNPq. MINITAB ${ }^{\circledR}$ is a trademark used with permission of Minitab Inc. in the United States. The authors are acknowledged to the anonymous reviewers and the editor Margriet ten Napel, who provided valuable suggestions and criticisms that helped to substantially increase the final version of the manuscript.

\section{References}

Andrade, G.O., 1955. Itamaracá. Contribuição para o estudo geomorfológico da costa pernambucana. Recife, Imprensa Oficial, 84 pp. 
Arai, M., 1997. Dinoflagelados (Dynophiceae) miocênicos do Grupo Barreiras do nordeste do estado do Pará (Brasil). Rev. Univ. Guarulhos, 2: 98-106.

Arai, M., Uesugui, N., Rossetti, D.F., Góes, A.M., 1988. Considerações sobre a idade do grupo Barreiras no nordeste do estado do Pará. 35 Cong. Bras. Geol., S.B.G., Belém, Brazil, 2, pp. 738-752.

Asner, G.P., 2001. Cloud cover in Landsat observation of the Brazilian Amazon. Int. J. Rem. Sens., 22: 3855-3862.

Azevedo, R.P., 1991. Tectonic evolution of Brazilian Equatorial Continental Margin Basins. Ph.D. Thesis, Univ. London, London.

Behling, H., Costa, M.L., 2000. Holocene environmental changes from the Rio Curuá record in the Caxiuanã region, eastern Amazon Basin. Quat. Res., 53: 369-377.

Behling, H., Cohen, M.C.L., Lara, R.J., 2001. Studies on Holocene mangrove ecosystem dynamics of the Bragança Peninsula in north-eastern Pará, Brazil. Palaeogeog., Palaeoclim., Palaeoecol., 167: 225-242. 
Bemerguy, R., 1997. Morfotectônica e Evolução Paleogeográfica da Região da Calha do Rio Amazonas. Doctoral Thesis, Univ. Fed. Pará, Belém.

Bezerra, P.E.L., 2003. Compartimentação morfotectônica do interflúvio Solimões-Negro. Ph.D. Thesis, Univ. Fed. Pará, Belém.

Costa, J.B.S., Hasui, Y., 1997. Evolução geológica da Amazônia. In: M.L. Costa, R.S. Angélica (Editors), Contribuições à Geologia da Amazônia. S.B.G., Belém, PA, pp. 1519.

Costa, J.B.S., Borges, M.S., Bemerguy, R.L., Fernandes, J.M.G., Costa Jr., P.S., Costa, M.L., 1993. A evolução cenozóica da região de Salinópolis, nordeste do Estado do Pará. Geociências, 12: 373-396.

Costa, J.B.S., Hasui, Y., Borges, M.S., Bemerguy, R.L., 1995. Arcabouço tectônico mesozóico-cenozóico da região da calha do Amazonas. Geociências, 14: 77-83.

Costa, J.B.S., Bermeguy, R.L., Hasui, Y., Borges, M.S. , Ferreira Jr., C.R.P., Bezerra, P.E.L., Costa, M.L., Fernandes, J.M.G., 1996. Neotectônica da região amazônicaaspectos tectônicos, geomorfológicos e deposicionais. Geonomos, 4: 23-44.

Costa, J.B.S.C., Bemerguy, R.L., Hasui, Y., Borges, M.S., 2001. Tectonics and paleogeography along the Amazon River. J. South Am. Earth Sci., 14: 335-347. 
Costa, M.L., Moraes, E.L., Behling, H., Melo, J.C.V., Siqueira, N.V.M., Kern D.C., 1997. Os sedimentos de fundo da Baía de Caxiuanã. In: P.L.B. Lisboa (Editor), Caxiuanã. Mus. Par. Em. Goeldi, Belém, pp. 121-137.

Costa, M.L., Kern, D.C., Behling, H., Borges, M., 2002. Geologia. In P.L.B. Lisboa (Editor), Caxiuanã: Populações Tradicionais, Meio Físico e Diversidade Biológica. Mus. Par. Em. Goeldi, Belém, pp.179-206.

Daemon, R.F., 1975. Contribuição à datação da Formação Altér do Chão, Bacia do Amazonas. Rer. Bras. Geoc., 5: 58-84.

Eastman, J. R., 1995. Idrisi for Windows: User's Guide. Worcester, Clark University, 440 pp.

Ferreira, C.S., 1966. Características lito-paleontológicas na Formação Pirabas, Estado do Pará. Conf. Geol. Guianas, 6: 101-111.

Ferreira, C.S., 1977. Fácies da Formação Pirabas (Mioceno Inferior): novos conceitos e ampliações. Na. Acad. Brás. Ciênc., 49: 353. 
Galvão, M.V.G., 1991. Evolução Termodinâmica da Bacia do Marajó, Estado do Pará, Brasil. M.Sc. Thesis, Univ. Ouro Preto, Ouro Preto.

Góes, A.M., 1981. Estudo Sedimentológico dos Sedimentos Barreiras, Ipixuna e Itapecuru, no Nordeste do Estado no Pará e Noroeste do Maranhão. M.Sc. Thesis, Univ. Fed. Pará, Belém, 55 pp.

Góes, A.M., Rossetti, D.F., 2001. Gênese da Bacia de São Luís-Grajaú. In: D.F. Rossetti, A.M. Góes, W. Truckenbrodt (Editors), O Cretáceo na Bacia de São Luís Grajaú. Mus. Par. Em. Goeldi, Coleção Friedrich Katzer, Belém, pp. 15-29.

Góes, A.M., Rossetti, D.F., Nogueira, A.C.R., Toledo, P.M., 1990. Modelo deposicional preliminar da Formação Pirabas no nordeste do Estado do Pará. Bol. Mus. Par. Em. Goeldi, Ser. Ciênc. Terra 2: 3-15.

Golden Software, 1995. Surfer Version 6.01- Surface Mapping System. Golden, Golden Software, Inc.

Kellndorfer, J., Walker, W., Pierce, L., Dobson, C., Fites, J. A., Hunsaker, C., Vona, J., Clutter, M., 2004. Vegetation height estimation from Shuttle Radar Topography Mission and Nation Elevation Datasets. Remote Sens. Envir., 93: 339-359. 
Leite, F.P.R., Oliveira, M.E.B., Arai, M., Truckenbrodt, W., 1997. Palinoestratigrafia da Formação Pirabas e Grupo Barreiras, Mioceno do nordeste do Estado do Pará, Brasil. Rev. Univ. Guarulhos, 2: 141-147.

Matoso, S.Q., Robertson, F.S., 1959. Uso geológico do termo Barreiras. Bol. Téc. Petr., 2: $37-43$.

Minitab Inc., 2000. Meet MINITAB, Release 13 for Windows. Pennsylvania, State College (not paged).

Moran, E.F., Brondizio, E., 1994. Integrating Amazonian vegetation land-use, and satellite data. Bioscience, 44: 329-338.

Pannatier, Y., 1996, VarioWin: Software for Spatial Data Analysis in 2D. New York, Springer-Verlag (not paged).

Petri, S., 1957. Foraminíferos miocênicos da Formação Pirabas. Bol. Fac. Filos., Ciênc. Let. Univ. São Paulo (Geol.), 216: 79 p.

Rabus, B., Eineder, M., Roth, A., Bamler, R., 2003. The shuttle radar topography mission-a new class of digital elevation models acquired by spaceborne radar. Photogramm. and Remote Sens., 57: 241-262. 
Research Systems Inc., 2002. Environment for Visualizing Images-ENVI Version 3.6. Boulder, $126 \mathrm{pp}$.

Rossetti, D.F., 2001. Late Cenozoic sedimentary evolution in northeastern Pará, Brazil, within the context of sea level changes. J. South Am. Earth Sci., 14: 77-89.

Rossetti, D.F., 2004. Paleosurfaces from Northeastern Amazonia as a key for reconstructing paleolandscapes and understanding weathering products. Sediment. Geol., 169: 151174.

Rossetti, D.F., Netto, R.G., 2005. First evidence of marine influence in the Cretaceous of the Amazonas Basin, Brazil. Cret. Res., in press.

Rossetti, D.F., Santos Jr., A.E., 2003. Events of soft sediment deformation and mass failure in Upper Cretaceous estuarine deposits (Cametá Basin, northern Brazil) as evidence for seismic activity: Sediment. Geol., 161: 107-130.

Rossetti, D.F., Santos Jr., A.E.A., 2004. Facies architecture in a tectonically-influenced estuarine incised valley fill of Miocene age, northern Brazil. J. South Am. Earth Sci., 17: 267-284. 
Rossetti, D.F., Toledo, P.M., 2006, Biodiversity from a historical geology perspective: a case study from Marajó Island, lower Amazon. Geobiology, in press.

Rossetti, D.F., Truckenbrodt, W., Góes, A.M., 1989. Estudo paleoambiental e estratigráfico dos Sedimentos Barreiras e Pós-Barreiras na região Bragantina, nordeste do Pará. Bol. Mus. Par. Em. Goeldi, Ser. Ciênc. Terra, 1: 25-74.

Rossetti, D.F., Góes, A.M., Truckenbrodt, W., 1990. A influência marinha nos Sedimentos Barreiras. Bol. Mus. Par. Em. Goeldi, Ser. Ciênc. Terra, 2: 17-29.

Santos Jr., A.E.A., Rossetti, D.F., 2003. Paleoambiente e estratigrafia da Formação Ipixuna, área do rio Capim, leste da Sub-bacia de Cametá. Rer. Brás. Geoc., 33: 313-324.

Simões, M.F., 1981. Coletores-Pescadores ceramistas do litoral do salgado (Pará). Bol. Mus. Par. Em. Goeldi, Ser. Antr., 78: 1-33.

Szatmari, P., Fraçolin J.B.L., Zanotto, O., Wolff, S., 1987. Evolução tectônica da margem equatorial brasileira. Rev. Bras. Geoc., 17: 180-188.

Toledo, P.M., 1989. Sobre novos achados de sirênios (Sirenotherium Pirabense, Paula Couto, 1967) na Formação Pirabas (Pará, Brasil). Bol. Mus. Par. Em. Goeldi, Ser. Ciênc Terra, 1: 5-10. 
Valeriano, M.M., 2002. Modelos digitais de elevação de microbacias elaborados com krigagem. Information and Documentation Service (SID), INPE, Tech. Rep. INPE9364-RPQ/736, 54 pp.

Valeriano, M.M., 2002b. Programação do cálculo da declividade em SIG pelo método de vetores ortogonais. Espaço e Geografia, 5: 69-85.

Valeriano, M.M., 2003. Curvatura vertical de vertentes em microbacias pela análise de modelos digitais de elevação. Rev. Bras. Eng. Agríc. Amb., 7: 539-546.

Valeriano, M.M., Carvalho Júnior, O.A., 2003. Geoprocessamento de modelos digitais de elevação para mapeamento da curvatura horizontal em microbacias. Rev. Bras. Geomorf., 4 : 17-29.

Valeriano, M.M., Kuplich, T.M., Storino, M., Amaral, B.D., Mendes Jr., J.N., Lima, D., 2006. Modeling small watersheds in Brazilian Amazônia with SRTM-90m data. Comp. Geosci. (in press, corrected proof available on-line).

Villegas, J.M.C., 1994. Geologia Estrutural da Bacia do Marajó. M.Sc. Thesis, Univ. Fed. Pará, Belém.

Vital, H., 1988. Estudo do geossistema do Lago Arari, Ilha do Marajó, Pará. M.Sc. Thesis, Univ. Fed. Pará, Belém. 


\section{LIST OF FIGURES}

Fig. 1: Downloaded SRTM-90m data used in this study.

Fig. 2: Shaded relief of SRTM-90m original data (left) and resampled DEM (right).

Fig. 3: Excerpt of morphometric maps derived from refined SRTM data, showing the high variability of the topographic variables. Note the canopy effect by observing a forest clear cut at bottom right.

Fig. 4: Geologic map of the study area in the lowest Amazon drainage basin. Note the distribution of the Plio-Pleistocene/Pleistocene Post-Barreiras sediments, configuring a fan morphology that spreads in the north/northwest direction from the locality of Tucuruí. Observe also that the Tocantins River suddenly change from east-west (between the towns of Imperatriz and Marabá) to north-northwest, and then northeast direction. The inside boxes numbered I, II and III locate respectively fan sectors 1, 2 and 3 described in the text.

Fig. 5: Stratigraphy of the study area.

Fig. 6: SRTM data illustrating the southern fan sector. A) The funnel-shaped fanhead, where the margins of the paleovalley form straight segments related to faults (white 
lines) that disrupted Miocene and older rocks. The arrows in the upper side of this figure indicate remains of these rocks within the paleovalley, which is filled mostly by the Post-Barreiras sediments of Plio-Pleistocene to Pleistocene age (Box locates figure B and $A-A^{\prime}$ locates the topographic profile shown in C). B) Detail of figure A, highlighting abandoned meandering channels related to a paleo Tocantins River (dotted white lines). Note that might be channels segmented abruptly forming straight edges, which is related to faults (continuous white lines). C) Topographic profile obtained from the transect $\mathrm{A}-\mathrm{A}^{\prime}$ located in figure $\mathrm{A}$, which shows the asymmetric nature of the paleovalley margins, represented by a more gradual western side, and a sharp, almost vertical eastern margin adjacent to the present course of the Tocantins River (white arrows). (All figures obtained from SRTM images).

Fig. 7: SRTM data illustrating details of the mid fan sector. A) Abandoned meander complex of the paleo Tocantins River (dotted white lines). The arrow locates the point where a main abandoned channel is inflected eastwards, which is related to the influence of dextral E-W strike slip motion (straight white lines indicate indicate sharp segmentation of abandoned channels due to faults. B) two large areas (in yellow) from the eastern mid-fan sector with Holocene and modern sediments related to subsidence caused by tectonic activity, as suggested by numerous sharp lineaments in their margins (white lines) that parallels main NNW-SSE and NE/SW orientated faults. The segment A- $\mathrm{A}^{\prime}$ locates the topographic profile shown in figure $\mathrm{C}$. C) the topographic profile A$\mathrm{A}^{\prime}$, characterizing the lowest relief of the two areas with Holocene and modern sediments shown in B. (All Figures obtained from SRTM images) 
Fig. 8: SRTM data illustrating the northern fan sector. A) Contrast between the western and eastern sides of the Marajó Island, represented by Post-Barreiras and Holocene deposits, respectively. A narrow belt in the extreme eastern margin of this island is also represented by Post-Barreiras sediments. Note the complex of abandoned channels in the western side of the island, some of them ending abruptly in the contact with the Holocene sediments (arrows). (The three boxes locate figures C, E and F, and the segment A-A' locates the topographic profile shown in figure B). B) Topographic profile from segment A-A'shown in figure $\mathrm{A}$, illustrating that lower relief of the area with Holocene sediments relative to adjacent areas with Post-Barreiras sediments.

Fig. 9: SRTM data illustrating details of the northern fan sector. A) Detail of figure A, where a complex of meandering channels (mostly highlighted in blue colors) and associated crevasse splays (circles) are well preserved. (Box locates figure B). B) Close up of abandoned meanders shown in figure A. C) Detail of figure 8A where one of the Post Barreiras abandoned channels ends abruptly at the contact with the Holocene deposits. Note that this channel opens forming a funnel shape, typical of estuaries. D) A channel observed in the Post-Barreiras sediments locally segmented by NW-SE and NE-SW faults (see figure 8A for location).

Fig. 10: Diagrams illustrating the hypothetic evolution of the lowest Amazon drainage area from the Plio-Pleistocene to Present. A) Establishment of a paleovalley paralleling N/NW-S/SE orientated faults, which was fed by a paleo Tocantins River resulting in the 
initial deposition of the Post-Barreiras sediments. B) Fault reactivations along NNWSSE orientated strike slip zones would have captured the paleo Tocantins river, deviating it to its present NE direction and amplifying the paleovalley eastwards. This tectonic event was also responsible for the initial development of the Caxiuanã area which ultimately led to the enlargement of the paleovalley westwards. C) Activity along main E-W orientated strike slip zones promoted a further partitioning of the study area, leading to the origin of the Rio Pará River, which was responsible for detachment of the Marajó Island from mainland. Contemporaneous to this event, the eastern side of the Marajó Island subsided slightly, creating new space for sediment accumulation. These diagrams are provided only for illustrative purposes, thus the limits of the paleovalley northward and northwestward are plotted with question marks, as no data are provided here for a more precise reconstruction. 